\section{NÁRODNÍ ZDRAVOTNICKÝ INFORMAČNÍ PORTÁL: ZHODNOCENÍ PILOTNÍHO PROVOZU}

\section{Martina Bakešová, Vojtěch Bulhart, Miloš Hejný, Martin Komenda}

\begin{abstract}
Anotace
Národní zdravotnický informační portál (NZIP) byl spuštěn v červenci $2020 \mathrm{~s}$ ambicí poskytnout laické veřejnosti zcela nový garantovaný zdroj informací z různých oblastí českého zdravotnictví. Obsah publikovaný na NZIP je připravovaný předními odborníky a je zveřejňován pod záštitou Ministerstva zdravotnictví České republiky ve spolupráci s Českou lékařskou společností Jana Evangelisty Purkyně, Státním zdravotním ústavem a Ústavem zdravotnických informací a statistiky České republiky. Portál se postupně začal stávat místem s ověřenými informacemi, které občany dlouhodobě zajímají. Hlavním cílem celého projektu je srozumitelnou formou předat informace o nemocech, prevenci a vzdělávat veřejnost $v$ oblasti zdraví. Nedílnou součástí portálu je i mapa zdravotní péče, kde lze vyhledat nejbližšího poskytovatele a usnadnit tak propojení lidí se zdravotním problémem s jejich lékařem/specialistou. Příspěvek kriticky hodnotí rok provozu pilotní verze portálu, představuje nové kategorie a témata, stručně dokumentuje klíčové funkcionality a popisuje souhrnné výsledky analýzy chování uživatelů včetně dopadu na další rozvoj. Nechybí ani komunikační a marketingová strategie, která vznikla i přes komplikované období zasažené epidemií COVID-19. V rámci sdělení bude představen také další plán po vývojové i obsahové stránce.
\end{abstract}

\section{Klíčová slova}

NZIP, webový portál, zdravotnictví, garantovaná informace

\section{1 Úvod}

Národní zdravotnický informační portál (NZIP) byl spuštěn 23. července 2020, kdy se konala tisková konference ve spolupráci s Ministerstvem zdravotnictví ČR. V době spuštění obsahoval NZIP 756 článků a 63 externích zdrojů. Portál se postupně začal stávat místem s garantovanými informacemi, které občany této republiky tíží. Hlavním cílem portálu nikdy nebylo a nebude podporovat samoléčbu, ale srozumitelnými články predat informace o nemocech, prevenci a vzdělávat veřejnost $v$ oblasti zdraví. Unikátní funkcionalitou je také mapa zdravotní péče, kde je možné snadno vyhledat nejbližšího poskytovatele a usnadnit tak propojení lidí s problémem s jejich lékařem.

\section{Zhodnocení aktuálního stavu NZIP}

\subsection{Personální zázemí}

Veškeré personální kapacity a technické nároky, které jsou potřebné pro návrh, vývoj, testování a implementaci technického řešení, jsou zajištovány ÚZIS ČR. Základem je vývojový tým složený ze systémových analytiků, grafiků, webových designérů, databázových specialistů, vývojárư̊ webových aplikací, testerů a redaktorů. Koordinace a management celého projektu probíhá pod vedením Vědecké a řídicí rady NZIP, která zastřešuje a po odborné stránce garantuje zveřejňovaný obsah. Rada je složena ze zástupců $M Z$ ČR, vedení České lékařské společnosti Jana Evangelisty Purkyně, Státního zdravotního ústavu a ÚZIS ČR. Samotná př́íprava a následná publikace příspěvků na portálu je $v$ režii odborných redaktorů a editorů (zajistí technický převod dodaného obsahu do online podoby a nastaví potřebné atributy pro zveřejnění), kteří prímo podléhají zmíněné radě.

\subsection{Přehled dostupného obsahu}

V souladu s plánem projektu NZIP začala probíhat ihned od jeho zahájení intenzivní práce na tvorbě odborného obsahu, prístupného svou formou a rozsahem široké veřejnosti. Na této práci se podílí celá řada špičkových odborníků v oblasti zdravotnictví v rámci resortu, zástupců ze Státního zdravotního ústavu a České lékařské společnosti Jana Evangelisty Purkyně, která zahrnuje jednotlivé odborné lékařské společnosti a externí experty. Obsah je rozdělen do odborných textů neboli článků a externích doporučených zdrojů, které prostřednictvím krátké anotace odkazují na prověřené webové portály. Odborným týmem je zpracovávaná sada vybraných tematických kategorií, které jsou definované na základě požadavků Vědecké a řídicí rady. Ty popisují základní informace v rámci daných odborností, které jsou primárně určeny pro širokou laickou veřejnost v podobě mapy portálu nzip.cz (Obr. 1).

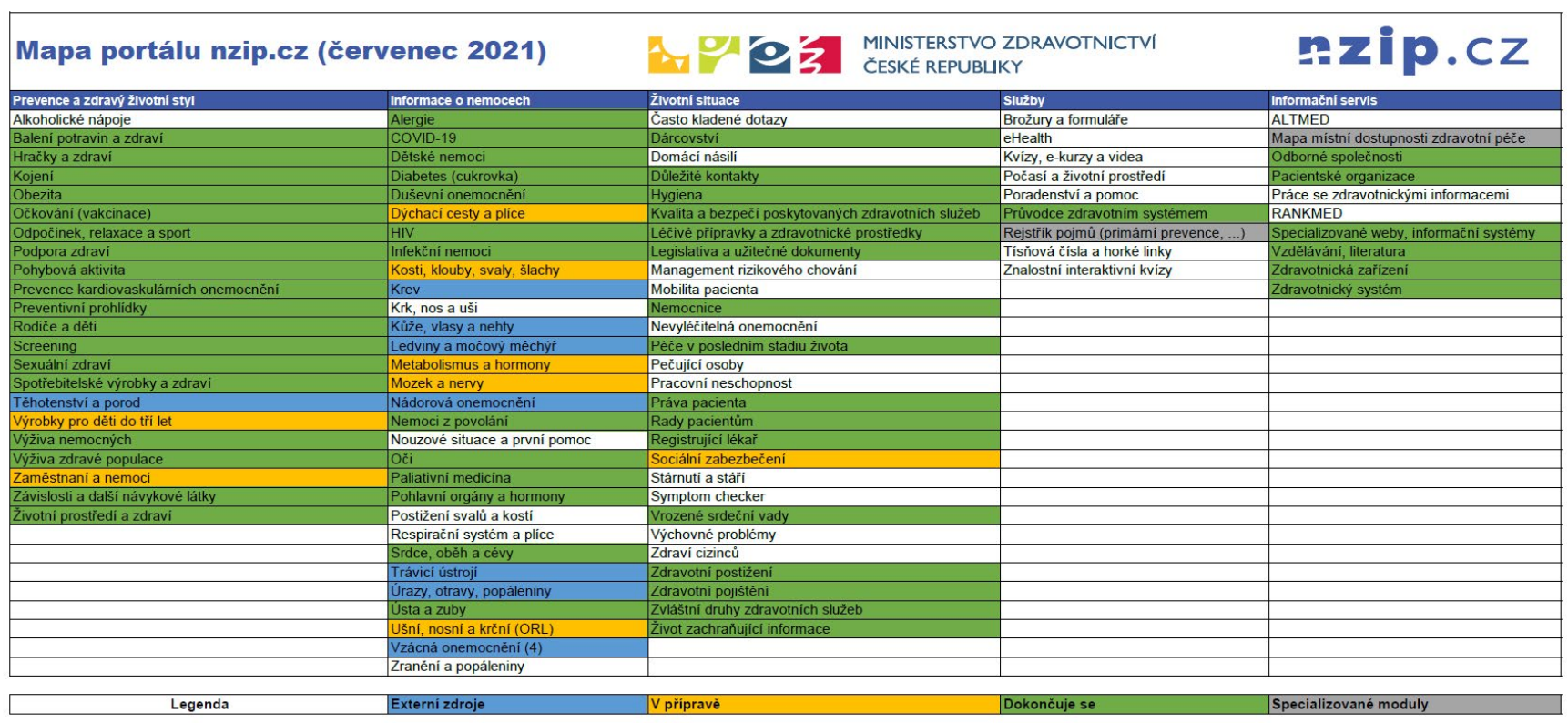


NZIP obsahuje také jistou formu medicínského slovníku v podobě portálového rejstř́ku, který je provázán s publikovaným obsahem v rámci jednotlivých článků/externích zdrojů a usnadňuje uživatelům orientaci a pochopení akcentovaných témat. $\checkmark$ dalších etapách rozvoje portálu budou rejstříkové pojmy nadále doplňovány ve spolupráci s odborníky tak, aby byl srozumitelný pro laickou veřejnost. Přehledový souhrn dostupného obsahu na NZIP (červenec 2021):

- 1070 publikovaných článků

- 270 externích zdrojů

- 39395 poskytovatelů zdravotní péče

- 2734 rejstríkových pojmů

V rámci indexace a publikace externích doporučených zdrojů, byly $v$ jednotlivých kategoriích a zpracovaných článcích umístěny odkazy na doporučené weby. Nejčastěji se jedná o weby pacientských organizací podle daného typu problematiky (90), odkazy na zdravotnická zařízení, doporučenou literaturu a odborné společnosti. Aktuálně se jedná o 146 doporučených odborných odkazů a webů. Nedílnou součástí NZIP byl také vznik pravidel pro objektivní hodnocení publikovaného obsahu tak, aby byla v maximální možné míře zajištěna kvalita a odborná hodnota všech interních i externích publikovaných příspěvků. Základem je odborná a laická recenze, která umožní odhalit prípadné nedostatky z obsahového a jazykového hlediska před zveřejněním. Nastavení dlouhodobých redakčních a garančních procesů je pravidelně konzultováno $s$ Vědeckou a řídicí radou v souladu s novými požadavky samotných autorů, garantů a recenzentů. Realizační tým NZIP nyní nadále pokračuje na obsahovém plnění portálu dle stanoveného publikačního plánu za účelem naplnění stanovených kategorií.

\subsection{Analýza chování uživatelů}

Pro sledování chování uživatelů a následnou analýzu jsou na portálu nasazeny dvě služby - Google Analytics a Microsoft Clarity. Kombinací dat těchto služeb získáváme dobrý přehled o tom, jak se uživatelé při své návštěvě portálu pohybují. Analýza z těchto dat se dále promítá do vývojového plánu a následné implementace nových prvků a funkcionalit pro zlepšení uživatelské př́ivětivosti z pohledu návštěvníků (Obr. 2).

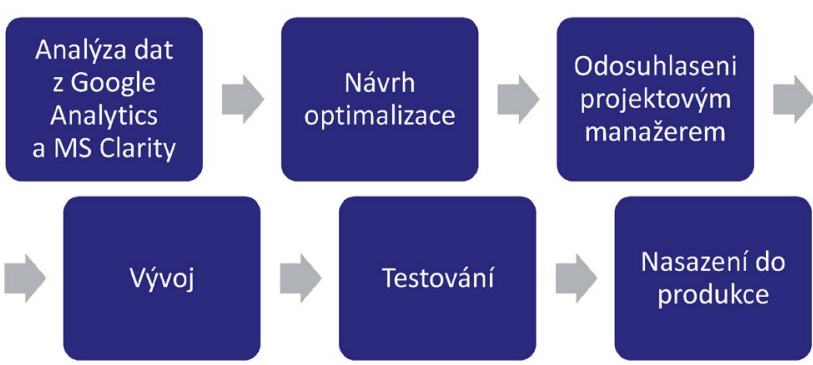

Obrázek 2 - Proces optimalizace webu

\subsubsection{Google Analytics}

Základní přehled dat z monitorovacích nástrojů za období 23. 7 . 2020 až 23. 7. 2021:

- 861420 - počet uživatelů

- 1071477 - návštěv

- 1790330 - zobrazení stránek

• 00:01:51 - průměrná doba návštěvy

• 33,91 \% - míra okamžitého opuštění

Z dat, která od spuštění portálu sbíráme, vidíme kontinuální růstový trend v počtu uživatelů, kteří NZIP navštívili (Graf 1). Na druhou stranu pozorujeme klesající trend v míře okamžitého opuštění, kdy uživatel na stránku NZIP přijde a bez následné interakce portál opustí, tedy zavře okno prohlížeče (Graf 2).

$Z$ dat můžeme vyvodit, že klíčovým cílem pro NZIP je důležité vyvolat $v$ uživatelích důvěru pomocí kvalitně a přehledně zpracované informace $s$ garancí správnosti. Vracející se návštěvník v průměru navštíví více stránek a zůstane na portálu déle (Tab. 1).

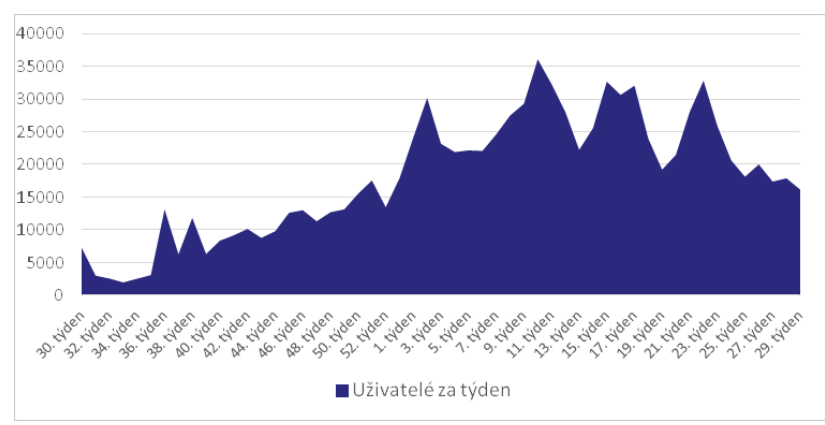

Graf 1 - Návštěvnost uživatelů na portálu nzip.cz (30. týden 2020 - 29. týden 2021)

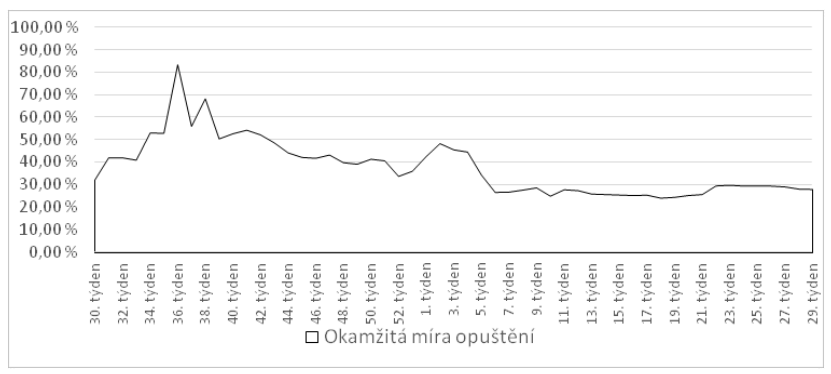

Graf 2 - Okamžitá míra opuštění portálu nzip.cz (30. týden 2020 - 29. týden 2021)

\begin{tabular}{|l|c|c|}
\hline & Nový uživatel & Vracející se uživatel \\
\hline Počet uživatelů & $87,80 \%$ & $12,20 \%$ \\
\hline $\begin{array}{l}\text { Navštívených } \\
\text { stránek }\end{array}$ & 1,57 & 1,82 \\
\hline $\begin{array}{l}\text { Průměrná délka } \\
\text { návštěvy }\end{array}$ & $0: 01: 39$ & $0: 02: 21$ \\
\hline
\end{tabular}

Tabulka 1 - Porovnání nových a vracejících se uživatelů portálu nzip.cz

Při vývoji platformy byl kladen velký důraz na správné technické řešení pro podporu indexace ve vyhledávačích, které $v$ kombinaci s unikátně tvořeným obsahem od autorů je promítnut v stoupající trend návštěv $z$ jednotlivých vyhledávačů (Graf 3).

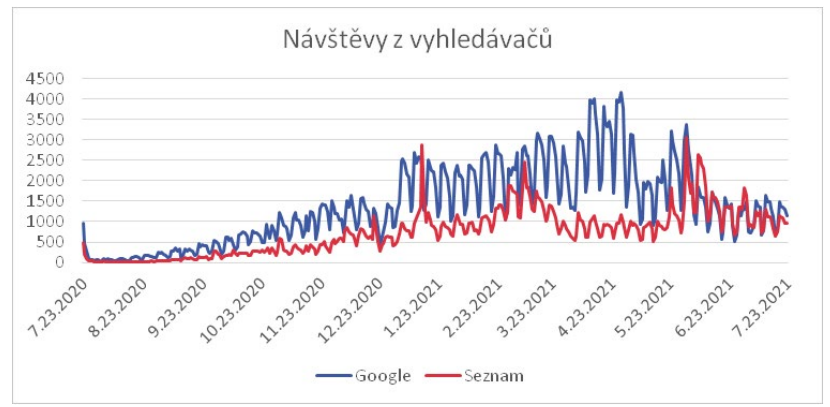

Graf 3 - Vývoj počtu návštěv portálu nzip.cz z vyhledávačů Google a Seznam (30. týden 2020 - 29. týden 2021) 
Díky správné indexaci ve vyhledávači Google se ve výsledcích na zadané dotazy drží NZIP průměrně na 9,4 pozici (první stránka výsledků na danou slovní frázi), kde jsme zaznamenali téměř 30 mil. zobrazení ve výsledcích hledání a přes 1,2 mil. prokliků na webové stránky. Dlouhodobá míra prokliku na web se drží okolo 4,2\%. Na určitá klíčová slova se podařilo portálu dostat i na první místo a mezi tzv. "Google Knowledge Graph Search", které pomáhají portálu získat nové návštěvníky (Obr. 3).

Avšak, dobrá indexace nemusí vždy zaručit uspokojení potřeb uživatelů. Dobrým př́kladem může být prudký nárůst na přelomu května a června 2021, kdy počet návštěv ze stránky seznam. CZ na NZIP byl téměř stejný jako z konkurenčního vyhledávače Google. Z dat Ize vyčíst, že nejnavštěvovanější stránkou na portálu v době prudkého nárustu byl doporučený zdroj Očkovací portál občana, na který se uživatelé dostali po zadání klíčového slova „očkovací portál občana“. Zdánlivě výborná indexace však přinesla i negativní stránku. Uživatelé, kteří měli předchozí špatnou zkušenost s vygenerováním očkovacího certifikátu na oficiálním webu nebo nějaký jiný problém týkající se certifikátu, se začali přes kontaktní formulář na portálu NZIP obracet s žádostí o pomoc. Jelikož portál neslouží jako technická podpora nebo poradna Ministerstva zdravotnictví nebo samotného očkovacího portálu, ale zpracovává a publikuje vybraná zdravotnická témata, nebyl uživatelům v tuto chvíli portál platný a neuspokojil jejich potřeby. Tito uživatelé byli přesměrování na odpovídající osoby či weby zabývající se touto tématikou. To se v budoucnu může negativně promítnout do návštěvnosti, jelikož uživatelé si mohou NZIP spojit s jejich negativním zážitkem.

\subsubsection{Microsoft Clarity}

Analytická platforma Microsoft Clarity od společnosti Microsoft má za cíl pomoci optimalizovat prostředí webové stránky, tak aby průchod webem byl pro návštěvníka co nejjednodušší. Anonymizované nahrání obrazovky a míst, kam se návštěvník myší pohybuje a kliká, umožňuje UX designérům připravit optimalizaci jednotlivých komponent. Hlavní parametry, které využíváme pro optimalizaci komponent, jsou "Dead clicks" (místa, kde návštěvník kliká, ale stránka na ně nijak nereaguje) a „Rage clicks" (velká frekvence kliku návštěvníka v malé oblasti webové stránky). Tyto parametry nám umožní se $v$ kombinaci s vygenerovanou "Heat mapou“ zaměřit na části webu (Obr. 4), které mohou našemu návštěvníkovi znepř́jemnit průchod webem a v nejhorším prípadě v něm zanechat ve spojení s NZIP negativní zážitek a jeho budoucí neochotu vůbec na NZIP znovu prijít.

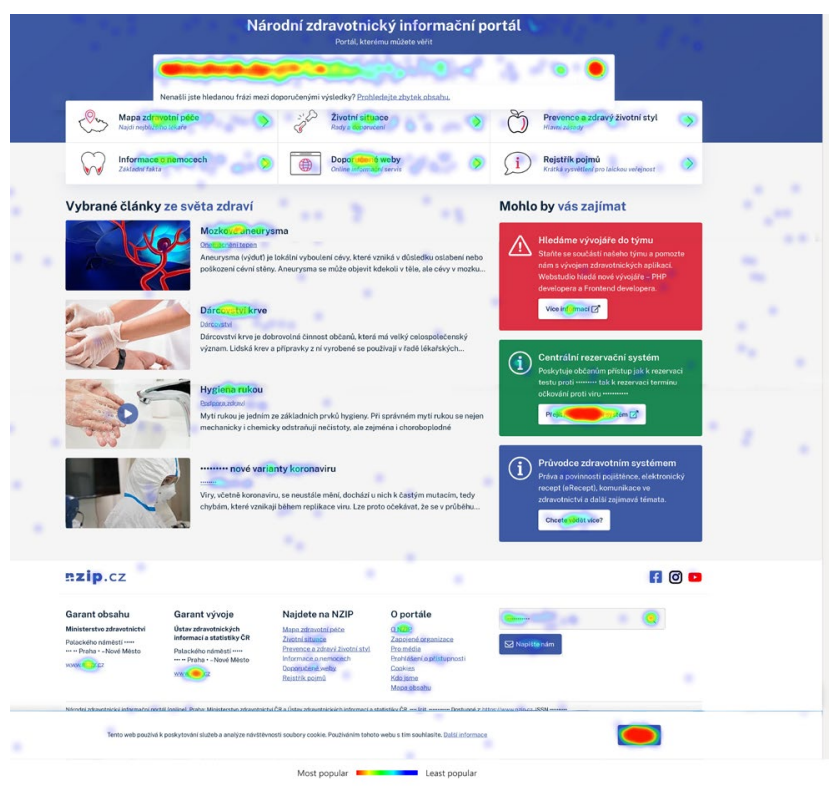

Obrázek 4 - Heat mapa domovské stránky portálu nzip.cz

\subsection{Komunikační strategie}

Nedílnou součástí webové prezentace je i komunikační strategie, která má za primární cíl zvýšit povědomí o značce NZIP a vybudovat v návštěvnících portálu spojení, že NZIP je důvěryhodný zdroj z oblastí zdravotnického sytému, zdravotního životního stylu a prevence. Motivací je uživatele informovat články, které zpracovávají odborníci na danou problematiku a vzdělávat v oblasti zdravotnické gramotnosti, ve které není dle průzkumů česká populace $v$ rámci Evropské unie premiantem. V současné době jsou hlavními komunikačními nástroji NZIP sociální sítě Facebook (https://www.facebook.com/nzip.cz) a Instagram (htt-

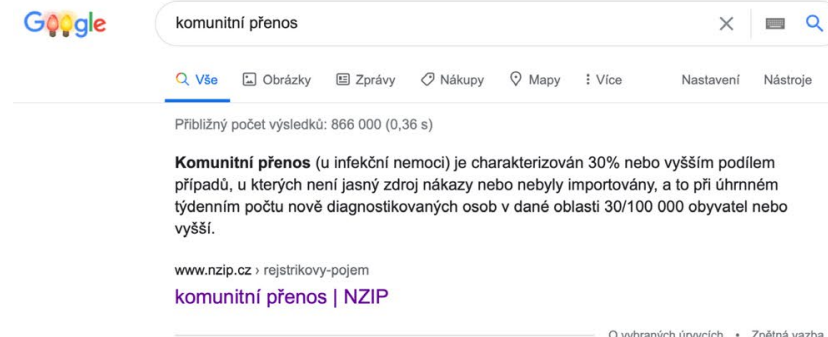

Slovniček pojmů - O koronaviru

Komunitni p̌̃enos - nákaza člověka bez vazby na osoby, která navš́tivily oblast is

prokazatelinym výskytem onemocněni. Koronaviry - svüj název dostaly podle

umw.mzcr..z , tiskove-centrum-mz, komunitni-preno...

Komunitni přenos covid-19 je již v pĕti krajích - Ministerstvo ... 9. 10. 2020 - Ve druhém oranžovém stupni pohotovostit, který se vyznazuuje pơ̌ínajićím

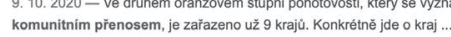

koronavirus mecrez tromuitniprenos-covid-19-je-ji...

Komunitní přenos covid-19 je již v pěti krajích - Aktuální ...

9. 10. 2020 - Ve trétim stupni pohotovosti, který znači komunitní prenos, jsou aktuálnẻ

Středočeský, Jihomoravský, Zlinský a Královêhradecký kraj, Nadále v

www.sneh.cz _ _texty , konf_2017_1_1 V PDF

Nemocniční a komunitní infekce - realita, hrozby a ... - SNEH Přenos v $0.3 \%$ je rizikovy pro HIV - Transplantaci napĭ, rohovky nelze vylouçit prenes

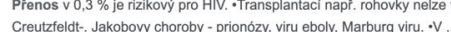

Govgle

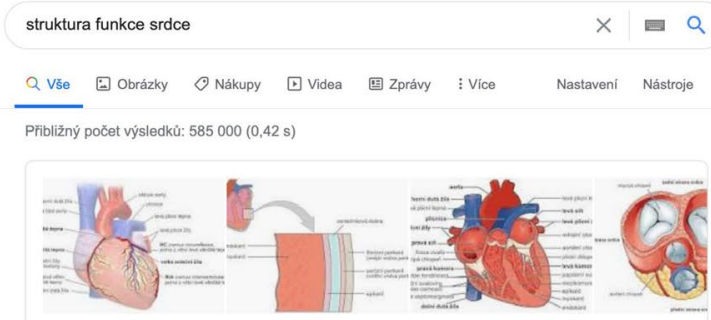

Srdečni funkce

Srdce se skládá ze čtyr̆ části, které se str̆idavě stahuji a uvolñuji: jsou to levá siñ, levá komora, pravá siñ a pravá komora.

unw..zzip.cz > clanek , 912-srdce-struktura-a-funkce

Srdce: struktura a funkce | NZIP

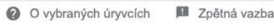

Srdce - WikiSkripta

22. 3. 2020 - 4 Cévni zásobeni srdce; 5 Srdečni skelet; 6 Srdeǒni chlopně ... vazivo,

nacházejici se zde struktury preveodn iho systému srdečniho). ... analogicky jako pulmonál

chlopeñ obsahuji l lunulae (ztenčeni) a noduli se stejnou funkci:

Anatomie srdce $\cdot$ Histologie srdce $\cdot$ Dutiny srdečn $\cdot$ Prứtok krve srdcem

cs. wikipedia.org , wiki , Srdce

Srdce - Wikipedie

Stęny sini maji méně svaloviny než stēny komor, protože vykonávaji menši činnost. Obsahuje

Stêny sini maji mené svaloviny neż stêny komor, protoże vykonáva
nervy, které určuji rytmus srdečninho tepu. Ve stredohrudi je srdce

nervy, kere urcuji rytmus srdeçnino tepu. Ve ste

Transporace 
ps://www.instagram.com/nzip.cz), kde je snaha o informování o nových článcích a aktuálních tématech. Další rozvoj komunikační strategie je aktuálně zpracováván ve spolupráci s interním týmem projektu NZIP a kreativní marketingovou agenturou.

\subsection{Souhrn nových funkcionalit}

V reakci na kontinuální sběr nových požadavků, zpětnou vazbu od uživatelů, interní i externí testování a samotné rozšiřování nových funkcí se NZIP neustále rozvíjí. Ty zásadní moduly a funkce jsou přehledově popsány v následujících kapitolách.

\subsubsection{NZIP Hry}

NZIP hry jsou interaktivní formou testování znalostí z oblasti zdravotnictví. Uživatel prochází postupně obrazovky s popisem konkrétní situace, která je doplněna o obrázky či videa, a dle svých znalostí se rozhoduje pro výběr jedné z nabízených odpovědí. Každá odpověd' přitom vede na jinou situaci, takže scénář hry není uživateli dopředu známý a závisí na individuálním průchodu hrou. Hry jsou vytvářeny přímo $v$ administračním rozhraní postupným provazováním jednotlivých obrazovek. Každý uzel má kromě odpovědí a popisné části také definovanou optimální dobu odpovědi, která se projevuje v následném vyhodnocení. V koncovém uzlu, který již neobsahuje žádné odpovědi, je hráči poskytnuta zpětná vazba. Výsledné pořadí se uživatel dozví na základě skóre, které zohledňuje váhy jednotlivých odpovědí a taktéž čas potřebný pro volbu jednotlivých odpovědí. Uživatelé (hráči) neprochází žádnou registrací, je tedy anonymní. I přesto je třeba nějakým způsobem hráče identifikovat, především kvůli následné analýze chování hráčů a uchování aktuálního stavu dané hry. K autentizaci je využitý token předávaný klientem při každém požadavku. Ten je zapsán jako identifikátor u každé akce v NZIP, na základě něhož jsou kontrolovány povolené akce.

\subsubsection{Odhalování odkazů na neexistující zdroje}

Odkazů na externí zdroje se na portálu vyskytují tisíce, at' už v článcích, doporučených zdrojích, popisech kategorií, popisech rejstríkových pojmů či u statických stránek. Neaktivních odkazy v takovémto počtu již nebylo možné spolehlivě odhalovat, a proto bylo nutné prijít $s$ automatizovaným řešením. Periodicky spouštěný crawler (specializovaný webový robot) najde všechny odkazy, které se na portále vyskytují a prověří jejich dostupnost. Na každou adresu je zaslán požadavek pomocí knihovny CURL a následně se vyhodnotí pouze kód odpovědi. Seznam nefunkčních odkazů je společně s konkrétním místem výskytu nakonec zaslán správcům obsahu, kteří mohu odkaz modifikovat.

\subsubsection{Alternativní formy $\mathrm{v}$ rejstříkových pojmech}

Ke každému rejstř́kovému pojmu je nově možné přiřadit jeho alternativní formy. Jde nejčastěji o vyskloňovanou variantu či o zkratku daného pojmu. Tyto varianty odkazují na tentýž pojem a sdílí tedy i stejný popis. Každý pojem by měl však být zvýrazněn nanejvýš jednou, a to v jakékoliv variantě. Protože je zapotřebí klíčová slova průběžně modifikovat a přidávat, bylo nutné provádět jejich vyhledávání v textu nejen při editaci či vzniku konkrétního článku, ale zaručit jejich aktualizaci napříc všemi příspěvky. Zvýraznění pojmů je totiž před-uložené, aby se docílilo maximální rychlosti načtení daného příspěvku. Přegenerování obsahu probíhá jednou týdně, což je tedy maximální interval, kdy se nový rejstř́íkový pojem ve starším článku ještě neobjeví.

\subsubsection{Interní kategorizace poskytovatelů zdravotní péče}

V rámci uživatelského testování bylo často zmiňováno, že by kategorizace poskytovatelů měla probíhat především dle problému, který chce daný uživatel řešit, a nikoliv dle lékařského oboru. Uživatel totiž dopředu nemusí ani tušit, jakého konkrétního oboru se jeho problém týká. Každý obor byl tedy stromovou strukturou přiřazen $\mathrm{k}$ určité nadřazené kategorii problémů, která mohla ještě odkazovat na jinou rodičovskou kategorii. Při importu poskytovatelů z NRPZS je tedy každý subjekt rovnou přiřazen do kýžené podkategorie. Při tomto procesu byla navíc zavedena validace poskytovatelů, nebot' se v registru občas vyskytují poskytovatelé beze jména, priǐrazené adresy či kontaktu. Takoví poskytovatelé jsou nyní automaticky reportováni správcům NRPZS.

\subsubsection{Vylepšení morfologické analýzy vyhledávaných frází}

Pomocí úpravy konfigurace nástroje Solr (platforma pro vyhledávání v textu) došlo k přesnějšímu vyhodnocení shody u vyhledávání. Byla definována slova, která nepodléhají standardnímu procesu stematizace (nalezení kořene slova) a jejich tvary byly přidány do slovníku synonym. Ten může obsahovat taktéž zkratky či alternativní varianty slov.

\subsubsection{Uživatelská tvorba statických stránek}

Kvůli častým potřebám úprav statických stránek byla vytvořena administrační sekce, kde je možné tento statický obsah obsluhovat pomocí WYSIWYG editoru. Krom samotné editace textu Ize nastavit i unikátní URL, pod kterou bude obsah nově dostupný. Toho je využito i při tvorbě tzv. přesměrování stránek, které slouží pouze jako prostředník, který přesměruje dotaz na další zdroj. Toho Ize využít při změnách umístění zdroje na portálu či pro tvorbu clean URL (srozumitelný a URL specifikaci dodržující textový řetězec).

\subsubsection{Vylepšení SEO a analytiky webu}

Metatagy (tagy neboli značky, které pomáhají vyhledávačům snáze identifikovat, co se na stránce nachází a co se na ní uživatelé mohou dozvědět) u článků a poskytovatelů byly rozšíreny tak, aby je bylo možné sdílet na sociálních sítích a byl zachován správný náhledový obrázek a popis. U četně zobrazovaných zdrojů byla vytvořena AMP verze (technologie pro rychlé zobrazení stránek na mobilním zařízení) a přidán skript na strukturovanou indexaci pomocí Google Rich Data. Byl taktéž implementován systém MS Clarity pro detailní analýzu pohybu uživatele na portálu.

\section{Diskuze}

Na portálu nzip.cz kontinuálně pokračuje práce jednotlivých týmů, a to obsahově-odborného, analytického, publikačního, vývojového, metodického a administrativního. Činnost jednotlivých týmů a další rozvoj portálu nebyl výrazně omezen mimořádnými epidemiologickými opatřeními Ministerstva zdravotnictví České republiky. Za účelem naplnění stanovených cílů dochází k dalšímu doplňování portálu nzip.cz dle připraveného publikačního plánu. Ve spolupráci s odbornou agenturou je vytvářena marketingová a komunikační strategie, která by měla pomoci dostat portál do povědomí širší veřejnosti. Její realizace je plánovaná na základě tematických balíčků v pravidelných periodách. Významnou částí portálu jsou také tzv. NZIP hry a jejich rozvoj, díky kterým očekáváme taktéž zvýšení publicity NZIP. V současnosti realizační tým vytváří také rozhraní pro 
přehlednou prezentaci dat ve formátu otevřených sad s vazbou na centrální katalog otevřených dat ve zdravotnictví. S ohledem na stále trvající epidemiologickou situaci a priority $M Z$ ČR, je primární pozornost zaměřena na prípravu otevřených datových sad o COVID-19. Aktuálně probíhá fáze prípravy dat a publikace otevřených datových souborů, které budou následně dostupné prostřednictvím portálu nzip.cz. Současně probíhají práce na přípravě sady vizualizačních komponent pro interaktivní zobrazení datových sad. Vývoj konkrétních částí, jejich testování a implementace prvků na portálovou platformu nzip.cz je komunikován $v$ rámci pravidelných zasedání Vědecké a rídicí rady NZIP. Průběžné úpravy funkcionalit NZIP jsou prováděny také na základě specifických požadavků ze strany cílových skupin NZIP.

\section{Kontakt}

Ing. Martina Bakešová

e-mail: martina.bakesova@uzis.cz

Vojtěch Bulhart

e-mail: vojtech.bulhart@uzis.cz

Bc. Miloš Hejný

e-mail:milos.hejny@uzis.cz

RNDr. Martin Komenda, Ph.D. Kamenice 126/3, 62500 Brno

tel.: +420 725714940

e-mail: martin.komenda@uzis.cz https://uzis.cz/

https://nzip.cz/ 